of allogeneic and autologous hematopoietic stem cell transplantation in prognostically favorable acute myeloid leukemia with double mutant CEBPA. Blood 2013;122:1576-1582.

6. Graubert TA, Brunner AM, Fathi AT. New molecular abnormalities and clonal architecture in AML: from reciprocal translocations to whole-genome sequencing. Am Soc Clin Oncol Educ Book 2014:334-340.
7. Tiesmeier J, Czwalinna A, Müller-Tidow C, Krauter J, Serve H, Heil G, Ganser A, Verbeek W. Evidence for allelic evolution of C/EBPalpha mutations in acute myeloid leukaemia. Br J Haematol 2003;123:413-419.

8. Shih LY, Liang DC, Huang CF, Wu JH, Lin TL, Wang PN, Dunn P, Kuo MC, Tang TC. AML patients with CEBPA mutations mostly retain identical mutant patterns but frequently change in allelic distribution at relapse: a comparative analysis on paired diagnosis and relapse samples. Leukemia 2006;20:604-609.

๑Copyright 2019 by Turkish Society of Hematology

Turkish Journal of Hematology, Published by Galenos Publishing House

\title{
Progressive Hepatic Cirrhosis Early After Allogeneic Hematopoietic Stem Cell Transplantation in a Patient with Chronic Hepatitis C Infection
}

\author{
Kronik Hepatit C Enfeksiyonu Olan Hastada Allojenik Kök Hücre Nakli Sonrası Erken \\ Dönemde Progresif Karaciğer Sirozu
}

\author{
(1) Satoshi Kaito1, (1) Noriko Doki ${ }^{1}$, (1) Tsunekazu Hishima22, (1) Yasunobu Takaki³, (1) Kazuteru Ohashi1 \\ ${ }^{1}$ Tokyo Metropolitan Cancer and Infectious Diseases Center, Komagome Hospital, Hematology Division, Tokyo, Japan \\ 2Tokyo Metropolitan Cancer and Infectious Diseases Center, Komagome Hospital, Pathology Division, Tokyo, Japan \\ ${ }^{3}$ Tokyo Metropolitan Cancer and Infectious Diseases Center, Komagome Hospital, Radiology Division, Tokyo, Japan
}

To the Editor,

Hepatitis C virus (HCV)-infected allogeneic hematopoietic stem cell transplantation (allo-HSCT) recipients have a higher incidence of liver cirrhosis over long-term follow-up compared to recipients without HCV infection [1,2]. However, liver dysfunction related to HCV is usually mild in the first 3 months after allo-HSCT [3]. We present the progressive hepatic cirrhosis soon after allo-HSCT in an HCV-infected recipient. The clinical and histopathological features were very similar to fibrosing cholestatic hepatitis $(\mathrm{FCH})$ caused by $\mathrm{HCV}$ reactivation.

A 50-year-old woman with myelodysplastic syndrome with excess blasts- 1 was admitted to undergo allo-HSCT. The patient had a history of hepatitis $\mathrm{C}$ positivity (genotype 2a) for more than 20 years. Liver enzyme levels at admission were slightly elevated (aspartate aminotransferase $57 \mathrm{U} / \mathrm{L}$, alanine aminotransferase $61 \mathrm{U} / \mathrm{L}$, alkaline phosphatase $434 \mathrm{U} / \mathrm{L}$, cholinesterase $115 \mathrm{U} / \mathrm{L}$, total bilirubin (T-Bil) $1.2 \mathrm{mg} / \mathrm{dL}$, and hepatitis $C$ viral load $2.5 \times 10^{4} \mathrm{IU} / \mathrm{mL}$ ). The serological tests for hepatitis B virus (HBV) and polymerase chain reaction for HBV-DNA were negative. Computed tomography (CT) demonstrated hepatosplenomegaly. Abdominal ultrasonography (US) showed coarse hepatic echostructure over the entire liver with a dull edge, smooth surface, and straight hepatic vein without ascites or any signs of portal hypertension. Liver biopsy was not performed because of thrombocytopenia.

Just before transplantation, no risk factors except for the mild hepatic dysfunction and age were found, the hematopoietic cell transplantation-comorbidity index ( $\mathrm{HCT}-\mathrm{Cl}$ ) was 1 , and the age-adjusted HCT-Cl score was $2[4,5]$. Meanwhile, bone marrow examination revealed active disease with 6.7\% myeloblasts. Considering the situation, the patient underwent peripheral blood stem cell transplantation from her human leukocyte antigen-identical sibling after myeloablative conditioning with cyclophosphamide $(120 \mathrm{mg} / \mathrm{kg})$ and total body irradiation (12 Gy). Considering drug-induced liver dysfunction, we avoided the use of busulfan. Cyclosporine and short-term methotrexate were used for graft-versus-host disease (GVHD) prophylaxis. After neutrophil engraftment, T-Bil was elevated up to $8.3 \mathrm{mg} / \mathrm{dL}$ and hepatitis $\mathrm{C}$ viral load was noted to have increased to $4.0 \times 10^{6} \mathrm{IU} / \mathrm{mL}$ on day 36 after allo-HSCT. Methylprednisolone was started at $1 \mathrm{mg} / \mathrm{kg} /$ day on day 36 for acute GVHD, with gradual improvement in liver test results. We performed deliberate observation of the patient with weekly US and monthly CT 
after allo-HSCT, which revealed progressive liver atrophy accompanied with ascites.

On day 82 after allo-HSCT, the patient once again became jaundiced and hepatitis C viral load increased over $6.9 \times 10^{7} \mathrm{IU} / \mathrm{mL}$. Transjugular liver biopsy showed bridging and pericellular fibrosis with architectural distortion, prominent ballooning, and spotty necrosis, consistent with early cirrhotic changes, and severe hepatocyte damage (Figures 1A-1D). There was mild portal inflammation without histologic evidence of the small bile duct changes of GVHD. Moreover, there was no sinusoidal obstruction. It was unlikely that the hepatopathy would be caused by cyclophosphamide, considering the timing of administration. From the pathological findings and the increased viral load, HCV reactivation was assumed to be the cause of liver dysfunction. Direct-acting antiviral (DAA) therapy with ledipasvir (90 mg/day) and sofosbuvir (400 mg/day) was started on day 110 after allo-HSCT. Although the viral load
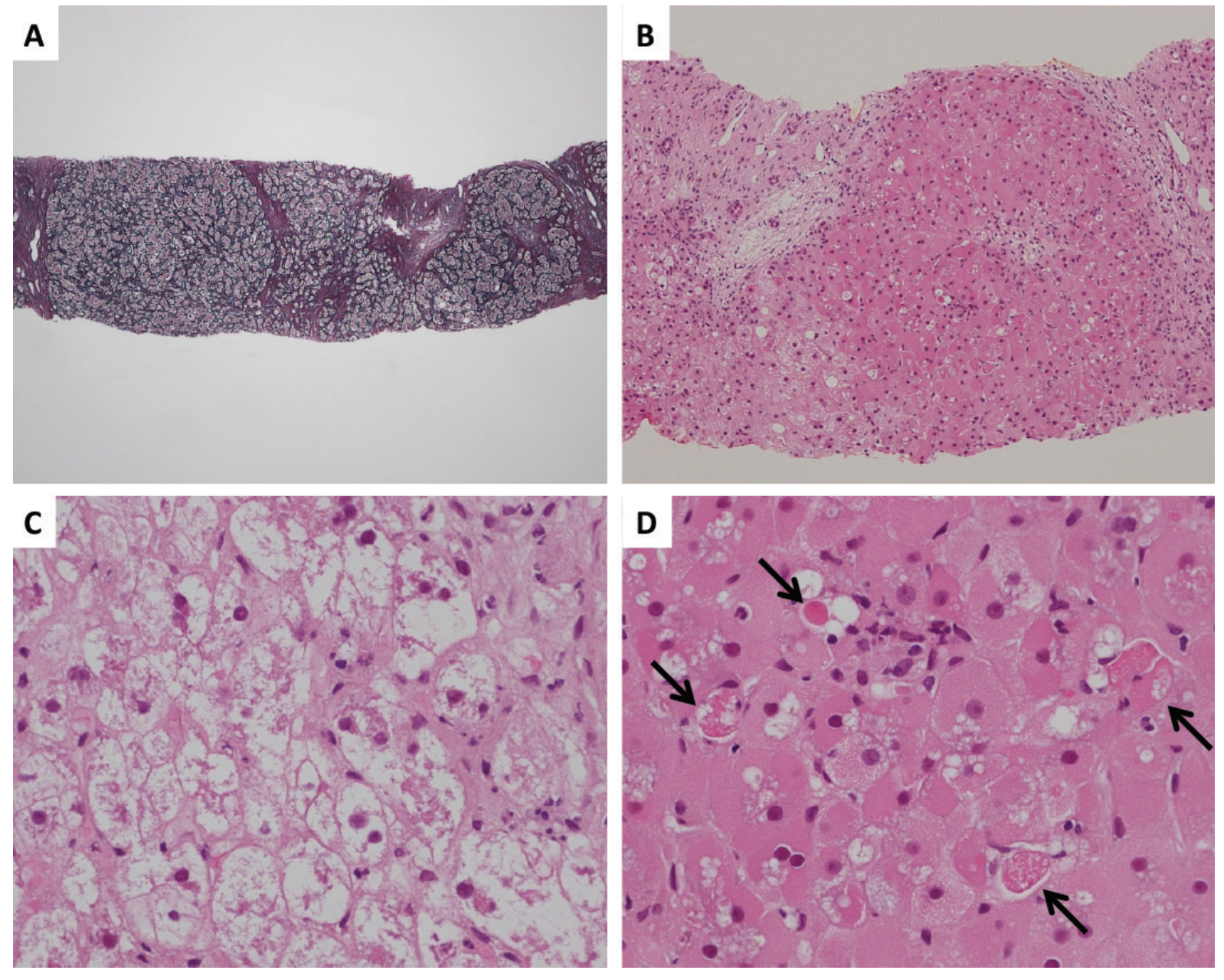

Figure 1. Photomicrographs of transjugular liver biopsy specimen on day 82 after transplantation, when the patient once again became jaundiced and hepatitis C viral load increased. A) There was extensive bridging and pericellular fibrosis with architectural distortion (silver staining, low power field). B) There was severe damage to hepatocytes. Lymphoid infiltration of the portal region was scarce (hematoxylin and eosin staining, low power field). C) Ballooning degeneration of hepatocytes was evident (hematoxylin and eosin staining, high power field). D) The hepatocytes varied in size with oxyphilic and vacuolated cytoplasm. Scattered focal necrosis was evident (black arrow) (hematoxylin and eosin staining, high power field). 


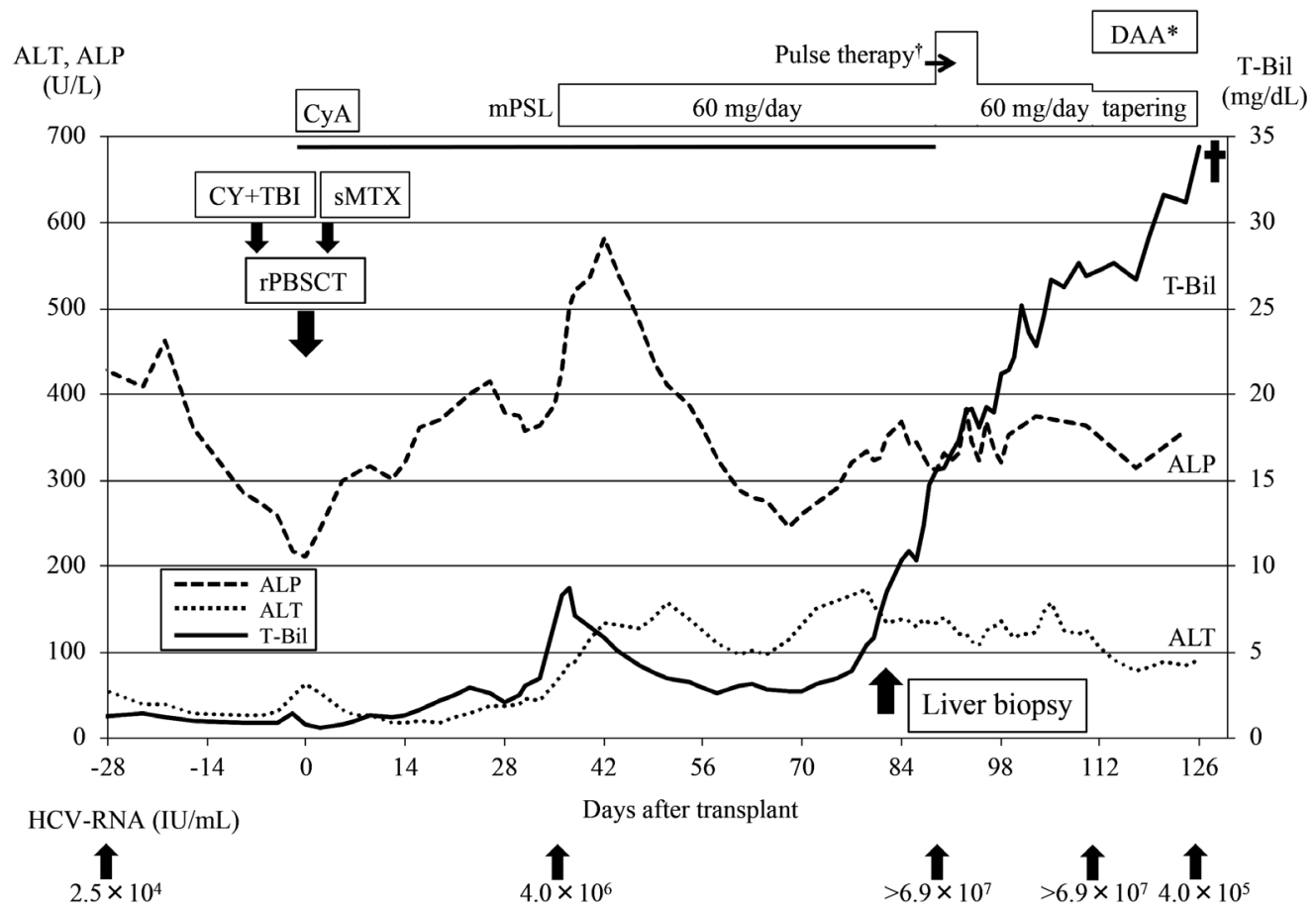

Supplementary Figure 1. Clinical course of the patient showing serial changes in her liver function.

DAA: Direct-acting antiviral therapy, CyA: cyclosporine; mPSL: methylprednisolone, CY: cyclophosphamide, TBI: total body irradiation, rPBSCT: peripheral blood stem cell transplantation from related donor, ALP: alkaline phosphatase, ALT: alanine aminotransferase, T-Bil: total bilirubin, HCV: hepatitis C virus.

*DAA included ledipasvir (90 mg/day) and sofosbuvir (400 mg/day). †1000 mg of methylprednisolone was administered for 3 days.

or potential drug-drug interactions of DAA with other agents [9]. In this case, we started DAA therapy based on the liver pathology and the increased HCV viral load. However, earlier intervention with DAA soon after the initiation of corticosteroid therapy should be considered, because it is a major risk factor for viral replication.

There were some limitations of our clinical practice. First, pretransplant liver status was not fully evaluated. Elastography should be considered for accurate evaluation of the degree of fibrosis [10]. Second, reduced intensity conditioning should be considered to avoid HCV-associated hepatopathy, although in our case the HCT-Cl and age-adjusted HCT-Cl scores were relatively low. Last, as stated above, earlier diagnosis and intervention with DAA might contribute to good outcomes.

In conclusion, the possibility of HCV recurrence should be also considered as a cause of progressive hepatopathy early after allo-HSCT.

Keywords: Hepatitis C virus, Allogeneic hematopoietic stem cell transplantation, Liver cirrhosis, Early posttransplant period, Fibrosing cholestatic hepatitis

Anahtar Sözcükler: Hepatit $C$ virüs, Allojenik kök hücre transplantasyonu, Karaciğer sirozu, Erken posttransplant dönemi, Fibrozan kolestatik hepatit
Informed Consent: Obtained from the family of the patient.

Conflict of Interest: The authors of this paper have no conflicts of interest, including specific financial interests, relationships, and/or affiliations relevant to the subject matter or materials included.

\section{References}

1. Peffault de Latour R, Lévy $V$, Asselah T, Marcellin P, Scieux C, Adès L, Traineau R, Devergie A, Ribaud P, Espérou H, Gluckman E, Valla D, Socié G. Long-term outcome of hepatitis $\mathrm{C}$ infection after bone marrow transplantation. Blood 2004;103:1618-1624.

2. Ljungman $P$, Locasciulli $A$, de Soria VG, Békássy $A N$, Brinch $L$, Espigado I, Ferrant A, Franklin IM, O'Riordan J, Rovira M, Shaw P, Einsele $H_{\text {; Infectious }}$ Diseases Working Party of the European Group for Blood and Marrow Transplantation. Long-term follow-up of HCV-infected hematopoietic SCT patients and effects of antiviral therapy. Bone Marrow Transplant 2012;47:1217-1221.

3. Peffault de Latour R, Ribaud P, Robin M, Valla D, Marcellin P, Socié G, Asselah T. Allogeneic hematopoietic cell transplant in HCV-infected patients. J Hepatol 2008;48:1008-1017.

4. Sorror ML, Maris MB, Storb R, Baron F, Sandmaier BM, Maloney DG, Storer B. Hematopoietic cell transplantation (HCT)-specific comorbidity index: a new tool for risk assessment before allogeneic HCT. Blood 2005;106:29122919.

5. Sorror ML, Storb RF, Sandmaier BM, Maziarz RT, Pulsipher MA, Maris MB, Bhatia S, Ostronoff F, Deeg HJ, Syrjala KL, Estey E, Maloney DG, Appelbaum FR, Martin PJ, Storer BE. Comorbidity-age index: a clinical measure of biologic age before allogeneic hematopoietic cell transplantation. J Clin Oncol 2014;32:3249-3256. 
6. Satapathy SK, Sclair S, Fiel Ml, Del Rio Martin J, Schiano T. Clinical characterization of patients developing histologically-proven fibrosing cholestatic hepatitis C post-liver transplantation. Hepatol Res 2011;41:328-339.

7. Delladetsima JK, Boletis JN, Makris F, Psichogiou M, Kostakis A, Hatzakis A. Fibrosing cholestatic hepatitis in renal transplant recipients with hepatitis $\mathrm{C}$ virus infection. Liver Transpl Surg 1999;5:294-300.

8. Evans $A T$, Loeb KR, Shulman HM, Hassan S, Qiu WC, Hockenbery DM, Ioannou GN, Chauncey TR, Gretch DR, McDonald GB. Fibrosing cholestatic hepatitis $\mathrm{C}$ after hematopoietic cell transplantation: report of 3 fatal cases. Am J Surg Pathol 2015;39:212-220.
9. Kyvernitakis A, Mahale P, Popat UR, Jiang $Y$, Hosry J, Champlin RE, Torres HA. Hepatitis $C$ virus infection in patients undergoing hematopoietic cell transplantation in the era of direct-acting antiviral agents. Biol Blood Marrow Transplant 2016;22:717-722.

10. Ziol M, Handra-Luca A, Kettaneh $A$, Christidis $C$, Mal F, Kazemi $F$, de Lédinghen $\mathrm{V}$, Marcellin $\mathrm{P}$, Dhumeaux $\mathrm{D}$, Trinchet $\mathrm{JC}$, Beaugrand $\mathrm{M}$. Noninvasive assessment of liver fibrosis by measurement of stiffness in patients with chronic hepatitis C. Hepatology 2005;41:48-54.

๑Copyright 2019 by Turkish Society of Hematology

Turkish Journal of Hematology, Published by Galenos Publishing House

\title{
Venous Thromboembolism in a Young Girl with Duplication of the Inferior Vena Cava and Protein S Deficiency
}

\author{
Vena Kava Inferior Dublikasyonu ve Protein S Eksikliği Olan Genç Kızda Venöz \\ Tromboemboli
}

\author{
(D) Wei-Li Liao1, (D) Ming-Yang Shih1, (D) Jiaan-Der Wang2,3 \\ ${ }_{1}^{1}$ Department of Pediatrics, Taichung Veterans General Hospital, Taichung, Taiwan \\ ${ }^{2}$ Center for Rare Disease and Hemophilia, Taichung Veterans General Hospital, Taichung, Taiwan \\ ${ }^{3}$ Tunghai University, Faculty of Medicine, Department of Pediatrics, Taichung, Taiwan
}

\section{To the Editor,}

A previously healthy 13-year-old girl presented with a 3-day history of progressive swelling and pain in her left lower limb. She also complained of cough in the last 2 weeks. No trauma, surgery, travel, or medication was noted before this illness. Physical examination revealed significant swelling and tenderness in her left lower limb. The laboratory data showed a high level of D-dimer ( $13.0 \mathrm{mg} / \mathrm{L} \mathrm{FEU,} \mathrm{reference} \mathrm{range}<0.55$ $\mathrm{mg} / \mathrm{L}$ FEU). Multidetector computed tomography showed extensive emboli formation from the left calf region to the left ilio-femoral veins and duplication of the inferior vena cava (IVC) (Figure 1). Pulmonary ventilation-perfusion (V/0) scintigraphy revealed several mismatched areas diagnostic for bilateral acute pulmonary embolism. Tracing the family history, her father had developed venous thromboembolism (VTE) at the age of 40 years and was diagnosed with protein $\mathrm{S}$ deficiency. A thrombophilia screening in this patient identified severe protein $S$ deficiency (protein S activity: 2\%, reference range: 55\%-140\%). Other results, including levels of homocysteine, antithrombin III, and protein C activity, were within normal limits; factor II G20210, factor V Leiden G1691A, anti-cardiolipin antibody, and anti- $\beta 2$ - glycoprotein I IgM and IgG were all negative. Her symptoms and signs subsided after treatment with heparin, followed by warfarin for 3 months. The repeated measurement of protein $\mathrm{S}$ activity was 7\% after discontinuation of treatment with warfarin for one week. Given that two provoking risk factors were present, the patient continued to receive prophylactic therapy with warfarin.

Virchow's triad describes the three main factors contributing to thrombosis, which include hypercoagulability, vessel injury, and venous stasis. Congenital anomalies of IVC may predispose to VTE due to resultant venous stasis. Duplication of IVC is usually considered as asymptomatic and an incidental finding while performing retroperitoneal surgery or venous interventional radiology. However, an increasing number of studies suggest that cases of unprovoked VTE were associated with duplication of the IVC $[1,2,3,4]$. The ages of these patients ranged from 18 to 84 years. No pediatric patient was reported.

VTE is long considered to be far less common in children than in adults. Most pediatric VTE is provoked and occurs with multiple risk factors [5]. Genetic risk factors play an important role in children who develop VTE and thrombophilia screening 